\title{
The Study of Causal Relationship between Stock Market Indices and Macroeconomic Variables in Cote d'Ivoire: Evidence from Error-Correction Models and Granger Causality Test
}

\author{
Drama Bedi Guy Herve (Corresponding author) \\ School of Economics, Shanghai University 99 Shangda Road, Shanghai 200444, China \\ E-mail: dramsiben@hotmail.com/yahoo.fr \\ Bouphanuvong Chanmalai \\ School of Economics, Shanghai University, 99 Shangda Road, Shanghai 20044, China \\ Yao Shen \\ School of Economics, Shanghai University, 99 Shangda Road, Shanghai 200444, China \\ E-mail: yaoshen56@163.com
}

Received: June 4, 2011

doi:10.5539/ijbm.v6n12p146
Accepted: July 25, 2011 Published: December 1, 2011

URL: http://dx.doi.org/10.5539/ijbm.v6n12p146

\begin{abstract}
This paper investigates the role of macroeconomic variables on stock prices movement in Cote d'Ivoire. We utilize the stock price index (SPI) call BRVM10 to represent Cote d'Ivoire stock market and some relevant macroeconomic variables such as industrial production index (IPI), consumer price index (CPI), domestic interest rate $(I R)$, real exchange rate $(E X R)$ and real money supply $\left(M_{2}\right)$. We examine both long-run and short-run dynamic relationships between the stock market index and the economic variables with quarterly data covering the period of 1999:1 to 2007:4 using Johansen's multivariate cointegration test techniques. The study identified that there is cointegration between macroeconomic variables and Stock prices in Cote d'Ivoire indicating long-run relationship. The results of Impulse Response Function (IRF) and Forecast Error Variance Decomposition (FEVD) demonstrate that out of five macroeconomic variables selected, only consumer price index (CPI) and domestic interest rate (IR) are the key determinants of the stock price movements in Cote d'Ivoire. The Granger-causality test based on the vector autoregressive (VAR) analytical framework was employed to empirically reveal that there is strong bi-directional relationship between stock price index (SPI) and domestic interest rate (IR). Thus, changes in the domestic interest rate might be used to predict the future stock price movement. The research also found that macroeconomic factors are not appropriate indicators to forecast the future behavior of the stock index movements in Cote d'Ivoire.
\end{abstract}

Keywords: Stock prices market, Macroeconomic variables, VAR models, Granger-causality, IRF, FEVD

\section{Introduction}

During the last past three decades, the relationship between macroeconomic variables and stock market index has been an important debate subject for both financial and macro economists. It has been extensively studied in developed capital markets and literature on the variables date back to 1970s. However, multifactor models have been developed as an explanatory factor of the variation in equity prices and these studies have typically focused on developed markets. Despite there are a numerous studies that investigate the causal effect relationship between macroeconomic variables and stock market, both the academics and the practitioners have not arrived at a consensus on the causality's direction among these variables, which remained as a source of ambiguity.

Many economists believe that significant decrease in stock prices could be source of future recession, whereas large increase in stock prices may reflect the expectation towards future economic growth. However, there were controversy issues to doubt the stock market's predictive ability such as the 1987 stock market crashed followed by world recession and 1997 Asian financial crisis (Har, Tan, \& Lim, 2008). The investigations were focused on developed, emerging and both developed and emerging capital markets context and the extant literature reveals 
strong relationships between the above macroeconomic variables and stock returns. Literature reveals that asset pricing theories do not specify the underlying macroeconomic factors that influence stock prices. These studies include (Chen, Roll, \& Ross, 1986), (Fama, 1981), (Hamao, 1988), (Faff, 1988), Chen(1991), (Maysami \& Kho, 2001), and (Paul \& Mallik, 2001) have employed cointegration analysis to examine the relationships between stock returns and macroeconomic variables in developed countries like Japan, US, Australia, Canada and European countries. In most of the studies variable selection and empirical analyses are based on economic rationale, financial theory and investors' intuition (Chen, Roll, \& Ross, 1986), (Mukharjee \& Naka, 1995). These studies generally apply (Engle \& Granger, 1987) procedure or (Johansen, 1988) and (Juselius, 1990) approach in Vector Auto-Regression (VAR) Framework. A number of studies, for example, modeled relationships between US share prices and real economic activity (Abdullah \& Hayworth, 1993), (Chen, Roll, \& Ross, 1986), (Dhakal, Khandil, \& Sharma, 1993), (Geske \& Roll, 1983) and (Huang \& Kracaw, 1984) for investigating the relationships between the UK stock market and macroeconomic factors, while (Brown \& Otsuki, 1990), (Hamao, 1988), (Mukherjee \& Naka, 1995) study the Japanese market case. Moreover, (Fung \& Lie, 1990), (Kwon, Chung, Shin, \& Bacon, 1997) investigate the Korean market for any relationship with their respective macro variables. The outcomes of all these studies suggest that, with minor degrees of variation, fundamental macroeconomic dynamics are indeed influential factors for stock market returns.

In comparison to the above, the long-run relationship between stock market and the economic variables has received little attention of researchers, we cite (Mukherjee \& Naka, 1995), (Cheung \& Ng, 1988), (Maysami \& Kho, 2001) and (Nasseh \& Strauss, 2000). They utilized the cointegration introduced by (Engle \& Granger, 1987), to investigate the empirical long run relationships between stock market indices and both measures of economic activity and financial variables. These studies find that stock prices are related to expect future production through effect on the discounted value of changes in cash flows and dividends. Concerning the developing countries numerous studies have been done. For example, (Ibrahim, 1999) investigated the dynamic interactions between stock prices and macroeconomic variables for Malaysia. The results from the bivariate and multivariate analysis revealed that the stock market was informationally inefficient with respect to consumer prices, official reserves and credit aggregates. (Habibullah \& Baharamshah, 2000) examined the relationship between stock prices and five macroeconomic variables, namely, interest rate, price level, national income, money supply and real effective exchange rate. They also employed the (Toda \& Yamamoto, 1995) long-run Granger causality test for determining the association between integrated series without having to worry about the order of integration or cointegrating rank in the vector autoregression system. The results suggested that the stock prices led national income, price level and exchange rate, which also mean that stock market acted as a leading indicator for many macroeconomic variables. At the same time, money supply and interest rate were found to lead stock prices. The economic role of the stock markets in relatively less developed Asian countries is less clear. (Maysami \& Sims; 2002, 2001a, 2001b) employed the Error-Correction Modelling technique to examine the relationship between macroeconomic variables and stock returns in Hong Kong and Singapore (Maysami \& Sim, 2002b), Malaysia and Thailand (Maysami \& Sim 2001a). Through the employment of (Hendry, 1986) approach which allows making inferences to the short-run relationship between macroeconomic variables as well as the long-run adjustment to equilibrium, they analyzed the influence of interest rate, inflation, money supply, exchange rate and real activity, along with a dummy variable to capture the impact of the 1997 Asian financial crisis. The results confirmed the influence of macroeconomic variables on the stock market indices in each of the six countries under study, though the type and magnitude of the associations differed depending on the country's financial structure. (Islam, 2003) replicated the above studies to examine the short-run dynamic adjustment and the long-run equilibrium relationships between four macroeconomic variables (interest rate, inflation rate, exchange rate, and the industrial productivity) and the Malaysian Stock Exchange Composite Index. His conclusions were similar: there existed statistically significant short-run (dynamic) and long-run (equilibrium) relationships among the macroeconomic variables and the Malaysian stock returns.

In addition, (Chong \& Koh's 2003) results were similar: they showed that stock prices, economic activities, real interest rates and real money balances in Malaysia were linked in long run both in the pre- and post capital control sub periods. (Islam, 2003) showed a strong, significant long-run relationship between stock prices and macroeconomic factors (interest rate, bonds price, foreign exchange rate, price earning ratio, market capitalization, and consumer price index) during 1992-2001 in Thailand. (Vuyyuri, 2005) investigated the cointegrating relationship and the causality between the financial and the real sectors of the Indian economy using monthly observations from 1992 through December 2002. The financial variables used were interest rates, inflation rate, exchange rate, stock return and real sector was proxied by industrial productivity. Johansen (1988) multivariate cointegration test supported the long-run equilibrium relationship between the financial sector and the real sector, and the Granger test showed unidirectional Granger causality between the financial sector and real sector of the economy. Moreover in the literature, (Omran, 2003) focused on examining the impact of real interest rates as a key factor in the performance of the Egyptian stock market, both in terms of market activity 
and liquidity. The cointegration analysis through error correction mechanisms (ECM) indicated significant long-run and short-run relationships between the variables, implying that real interest rates had an impact on stock market performance. To come back to West African case, (Yayah, 2009) have used time-series data to examine the long-run and causal relationship between inflation and financial development in the West African Economic and Monetary Union countries by utilizing (Toda \& Yamamoto 1995) test. The empirical results show no evidence of long-run relationship between inflation and financial development for six countries and no causality for two countries. He found that financial development causes inflation in four countries then, evidence of reverse causation has been detected for only two countries. Overall, these results give support to the UEMOA (Note 1) criteria aiming at keeping inflation rate below the threshold of $3 \%$ as a prerequisite for sustainable growth and real convergence. (Loesse, 2009) reexamine the cointegrating and causal relationship between financial development and economic growth in the case of ECOWAS (Note 2) countries. To this end, he used the (Pesaran, Shin, \& Smith, 2001) approach to cointegration and the procedure for noncausality test of (Toda \& Yamamoto, 1995) and also utilized data from the World Bank (2007) and covers the period 1960-2005. He calculated exact bounds critical values and showed that there is a positive long-run relationship between financial development and economic growth in four countries, namely, Cote d'Ivoire, Guinea, Niger and Togo, and a negative one in Cape Verde and Sierra Leone. In addition, finance marked development causes growth only in Cote d'Ivoire and Guinea. (Tachiwou, 2010) examined the impact of stock market development on growth in West African monetary union by utilizing time series data over the period 1995 -2006 and analyzed both the short run and long run relationship by constructing an Error-Correction Model. He finds that stock market development positively affects economic growth in West African monetary union both in the short run and long run. Specifically, how does this less-developed market respond to changes in its fundamental economic variables, compared with the well-developed, well-organized, and more-efficient markets? It is hoped that this research can contribute to bridge the gap.

The objective of this paper is to investigate the causality between stock market and some relevant macroeconomic variables in Cote d'Ivoire. In actual fact, Cote d'Ivoire has experienced sustained and consistent growth over the years despite being affected by the disadvantages of a small country. The Stock Market of West African monetary union (BRVM) is fairly new, established in 1997. However, it is one of the best performing stock market in Africa. It is one of the seven stock markets which trade automatically in Africa. The remain part of this paper is organize as follows. In the next section we develop the structural model of our analysis, stock return framework, arbitrage pricing theory, and dividend discount model (DDM). Section 3 describes the estimation specification and the data sources. Section 4 presents and discusses the estimation results. Section 5 concludes.

\section{The model: Stock Return Framework, Arbitrage Pricing Theory, and Dividend Discount Model (DDM)}

\subsection{The Stock Return Framework}

The main literature of characteristics of stock return was studied by (Hsieh, 1988). He examined the statistical properties of daily rate of change of five foreign currencies from 1974 to 1983 . He found that the exchange rate distributions like the equity return distributions have similar characteristics. Specifically, both return distributions are leptokurtic (too small). Hsieh suggested that there are two competing explanations for the observed heavy tails of the distribution: (a) the data are identically distributed drawn from a heavy tail of distribution whose parameters remain fixed over time; (b) the data are not identically distributed but drawn from a distribution whose parameters vary over time. In addition, he documented the day-of-the-week effect for the exchange rate data. However, he concluded that the rejection of the i.i.d. hypotheses for the exchange rate data was not attributable to the presence of the day-of-the-week effect. In these studies, the empirical distributions of stock price changes over time yield a higher frequency of observations near the mean and the tails than would be expected for a normal distribution. The simple kurtosis is almost always found to be greater than 3 (the value expected for a normal distribution). This type of distribution is characterized as peaked and fat-tailed. Since the normality of the stock return distribution is the crucial assumption underlying financial theories and their empirical evaluations, the "fat-tailed" findings cast doubts on the validity of findings which assume the normal distribution of stock returns. At least two explanations of the observed kurtosis in stock returns are found in the literature. One suggests that stock returns are best described by a member of the class of distributions with infinite variance, "the stable paretian distribution" while the other suggests that stock returns are sampled form a mixture of distributions that have different variances "the mixture of distribution hypothesis" (Fama E. F., 1963) and (Mandelbrot, 1962) proposed that security returns follow a stable paretian distribution with an infinite variance. (Fama E. F., 1965) illustrated that stable paretian distribution has two crucial properties: (1) their stability under addition and (2) their limited distributions for sums of independent, identically distributed random variable (Note 3 ).

The mixture of distribution hypothesis or the subordinated stochastic theory is an alternative explanation for the 
observed fat-tail in the empirical distribution of stock returns. This hypothesis asserts that stock returns are sampled from a mixture of distributions which have different conditional variances. The Heteroskedasticity associated with such mixtures of normal distributions will result in larger values of the sample kurtosis. As a result, this hypothesis implies that the distributions of underlying parameters are nonstationary over time. (Clark, 1973), (Epps \& Epps, 1976), (Tauchen \& Pitts, 1983), (Harris, 1986), (Lamoureux \& Lastrapes, 1990), and (Richardson \& Smith, 1994) have presented evidence supporting the mixture of distribution hypothesis from their studies of the stock return volatility-volume relationship. These findings have suggested that stock price data be generated by a conditional stochastic process with a changing variance parameter which can be proxied by volume. Also, several researchers including (Praetz, 1972) and (Blattberg \& Gondeds, 1974), among others, have verified that if conditional variance follows an inverted gamma distribution, the resulting (posterior) distribution is the student $t$ which is a distribution with fat-tailed properties. In this study, the scope of hypotheses is delineated as follows:

$\mathrm{H}_{0 A}$ : The stock returns are normally distributed

$\mathrm{H}_{1 A}$ : The stock returns are not normally distributed.

The study employs two statistical tests to determine whether each return series is normally distributed: the chi-square goodness of fit test for normality of residuals by Klein (1974) and the Jarque-Bera statistic. According to (Jarque-Bera, 1987), the Jarque-Bera statistic is calculated as follows:

$$
\mathrm{JB}=\mathrm{n}\left[\mathrm{s}^{2} / 6+(\mathrm{k}-3)^{2} / 24\right]
$$

Where $\mathrm{n}=$ the number of observations; $\mathrm{s}=$ skewness; and $\mathrm{k}=$ kurtosis. (Note 4 ) We begin with the assumption that $\log$ price Pt follows a random walk without drift:

$$
H_{0}: P_{t}=P_{t-1}+\varepsilon_{t}, \quad \varepsilon_{t} \sim I I D\left(0, \sigma^{2}\right)
$$

Denote by $I_{t}$ the following random variable:

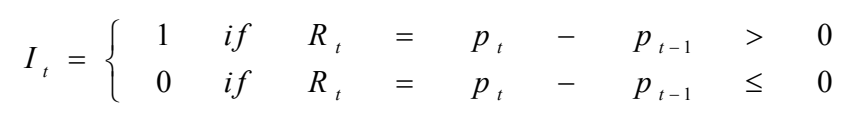

$I_{t}$ is a indicator variable indicating whether the $R t$ is positive or negative. Define $\mathrm{N} s$ and $\mathrm{N} r$ as the numbers of sequences and reversals respectively in historical stock return, where the former are pairs of consecutive returns with the same sign, and the latter are pairs of consecutive returns with opposite signs. Given a simple of $\mathrm{n}+1$ returns $\mathrm{R}_{1}, \mathrm{R}_{2}, \mathrm{R}_{n+1}$, the $\mathrm{N}_{s}$ and $\mathrm{N}_{r}$ can be expresses a simple functions of $I_{t}$ 's:

$$
\mathrm{N}_{s}=\sum_{t=1}^{n} y_{t}, \quad \mathrm{y}_{t}=I_{t} I_{t+1}+\left(1-I_{t}\right)\left(1-I_{t+1}\right)
$$

Where $\quad \mathrm{N}_{r}=\mathrm{n}-\mathrm{N}_{s}$

If we add the further restriction that the distribution of increments is symmetric, then whether Rt is positive or negative should be equally likely, which implies that for any pair of consecutive returns, a sequence and reversal are equally probable; hence the ratio $\hat{C} J=N^{s} / N^{r} \quad$ (Cowles \& Jones, 1937) should be approximately equal to one. Since returns at different time are independent under $\mathrm{H}_{0}, \hat{C} J$ can be interpreted as a consistent estimator of the ratio of the $1-\pi_{s}$, which is

$$
\hat{C} J=\frac{N_{s} / n}{N_{r} / n}=\frac{\hat{\pi}_{s}}{1-\pi_{s}}-\stackrel{P_{r}}{\longrightarrow} \frac{\pi_{s}}{1-\pi_{s}}=C J
$$

Under $\mathrm{H}_{0}, \pi_{s}=1 / 2, \mathrm{CJ}=1$. We need the asymptotic distribution of statistics $\hat{C} J=N_{s} /\left(n-N_{r}\right)$ which ban be derived by delta method from the distribution of $\mathrm{N}_{s}$. With $\mathrm{N}_{s}$ being a binominal random variable, i.e. the sum of $\mathrm{n}$ Bernoulli random variable $\mathrm{y}_{t}$ where:

$$
y_{\mathrm{t}}=\left\{\begin{array}{l}
1 \text { with probability } \pi_{s}=\pi^{2}+(1+\pi)^{2} \\
0 \text { with probability } 1+\pi
\end{array}\right.
$$


We may approximate the distribution of $N s$ for the large $\mathrm{n}$ by a normal distribution with mean $E\left(N_{s}\right)={ }_{n} \pi_{s}$ and variance $\operatorname{Var}\left(N_{s}\right)$. Because each pair for adjacent $y_{t}$ 's will be dependent (Note 5).

To investigate if the stock price changes exhibit nonlinear dependence, we use three tests such us the autocorrelation coefficients and Box-Pierce Q-statistics of the square residual of an autoregressive moving average (ARMA) model are examined. In a step by step process utilized by (Hsieh, 1988) to uncover the possible causes of the rejection of the i.i.d. hypothesis for the five exchange rates, be documented the day-of-the-week effect. However, he concluded that the rejection of the i.i.d. hypotheses for exchange rates was not attributable to the presence of the day-of-the-week effect. To test the day-of-the-week effect in stock returns this study, we follow 3 steps. i) investigates whether the day-of-the-week effect is present in the stock market data, ii) tests whether the distribution of stock returns changes across days of the week, and iii) Examines if the rejection of the i.i.d. hypothesis is attributable to the day-of-the-week effect. As a preliminary test, the study conducts a test of whether the day-of-the-week effect exists in the stock returns by running the following regression with binary dummy variables for each index to test whether there is any statistically significant difference among stock market returns, on different days of the week. The model which he estimated can be represented as follows:

$$
\mathrm{R}_{t}=\sum_{i=1}^{5} B_{i} D_{i t}+\mu_{t}
$$

Where $D 1 t=1$ if day $t$ is a Monday and 0 otherwise; $D 2 t=1$ if day $t$ is a Tuesday and 0 otherwise; and so on. The coefficients $B 1$ to $B 5$ are the mean returns for Monday through Friday, respectively. The stochastic error term is given by $u t$.Using the regression in equation (1), the following hypotheses are proposed and tested to determine the existence of the day-of-the-week effect in the West African Regional stock market.

$\mathrm{H} O D$ : Mean returns of each trading day are equal. (Days before and after holidays are included in the data set)

$$
(B 1=B 2=B 3=B 4=B 5)
$$

$\mathrm{H}_{1 D}$ : At least one trading day has a significantly different mean return.

In order to test whether the distribution of stock returns actually changes across the days-of-the-week, the data are categorized into five groups (Monday through Friday) in accordance with days of the week. We test the following null hypothesis of equal mean returns across days of the week:

$$
(B 1=B 2=B 3=B 4=B 5)
$$

If the daily returns are drawn from an identical distribution, they will be expected to be equal. However, the rejection of the null hypothesis would indicate a specific observable pattern in the stock market returns, thus violation of weak-form market efficiency.

\subsection{Arbitrage Pricing Theory}

The Arbitrage Pricing Theory (APT) was developed primarily by (Ross S., 1976a, 1976b). APT means that the expected return of a financial asset can be modeled as a linear function of various macro-economic factors or theoretical market indices, where sensitivity to changes in each factor is represented by a factor-specific beta coefficient (Note 6). It is a one-period model in which every investor believes that the stochastic properties of returns of capital assets are consistent with a factor structure. (Ross S., 1976a, 1976b) argues that if equilibrium prices offer no arbitrage opportunities over static portfolios of the assets, then the expected returns on the assets are approximately linearly related to the factor loadings. The APT is a substitute for the Capital Asset Pricing Model (CAPM) in that both assert a linear relation between assets' expected returns and their covariance with other random variables. The Capital Asset Pricing Model (CAPM) is based on the sufficiency of the mean variance framework for investment decision making. The asset pricing relationship is given as follow.

$$
\frac{E\left(R_{i}\right)-R_{f}}{\beta_{i}}=E\left(R_{m}\right)-R_{f}
$$

Where $E\left(R_{i}\right)$ is the expected return of the capital asset, $R_{f}$ is the risk free rate of interest, $\beta_{i}$ represents the sensitivity of the expected excess asset return to the expected excess market return, $E\left(R_{m}\right)$ is the expected return of the market and $E\left(R_{m}\right)-R_{f}$ is the market premium. Solving the equation in term of risk premium, we have. 


$$
\begin{gathered}
E\left(R_{i}\right)-R_{f}=\left[E\left(R_{m}-R_{f}\right)\right] \\
E\left(R_{i}\right)=-R_{f}+\left[E\left(R_{m}-R_{f}\right)\right]
\end{gathered}
$$

If we assume that $E\left(R_{i}\right)=u_{i}$ and $E\left(R_{m}\right)=u_{m}$ by substitution, we obtain the equation 12 as follow.

$$
u_{i}=r_{f}+\beta_{i}\left(u_{m}-r_{f}\right)
$$

Where $u_{i}$ and $u_{m}$ are the expected return of security $i$ and the market portfolio, respectively, and $r_{f}$ is the return on the free-risk security. The market portfolio is the value of all securities in the inverse. $\beta_{i}$ measures the systematic risk of the security and is estimated as the sensitivity of the security's returns to those of the market portfolio using the market model equation we obtain the following regression:

$$
r_{i t}=a_{i}+\beta_{i}+r_{m t}+e_{i t}
$$

Where $r_{i t}$ and $r_{m t}$ are period t returns on security $i$ and the market portfolio, respectively. The market model is view as the return generating model consistent with capital asset price model (CAPM), is utilized for event studies. If we consider the average returns on security, the market portfolio, and the free risk security are $\overline{r_{i}}, \overline{r_{m}}$ and $r_{f}$ respectively over the period $\mathrm{T}$, in the absence of any inferior or superior performance, the CAPM can be written as follow:

$$
\overline{r_{i}}=r_{f}+\beta_{i}\left(\bar{r}_{m}-r_{f}\right)
$$

Therefore, the difference $\alpha_{i}$ used to measure the performance is defined bellow.

$$
\alpha_{i}=\bar{r}_{i}-\left[r_{f}+\beta_{i}\left(\bar{r}_{m}-r_{f}\right)\right]
$$

The performance measure $\alpha_{i}$ popularly known as Jensen's alpha (Note 7) is usually estimated using an excess return market model:

$$
r_{i t}-r_{f}=a_{i}+\beta_{i}\left(r_{m t}-r_{f}\right)+\varepsilon_{i t}
$$

Considering the market return deviation $\delta_{m t}=r_{m t}-u_{m}$, and the market risk premium $\gamma_{m}=u_{m}-r_{f}$ we obtain the equation (17) bellow by substitution.

$$
r_{i t}-r_{f}=\alpha_{i}+\beta_{i}\left(\delta_{m t}+\gamma_{m}\right)+\varepsilon_{i t}
$$

Focusing on asset returns governed by a factor structure, the arbitrage price theory (APT) is a one-period model which covers the weakness of CAPM, in which preclusion of arbitrage over static portfolios of these assets leads to a linear relation between the expected return and its covariance with the factors. CAPM shows us a world in which $\beta$ is king, however, when investors hold different portfolios, the value of $\beta$ changes. When we measure the market portfolio differently (by taking a different broad index of stocks and shares), we get a different result for $\beta$. APT was developed to cover up these deficiencies. (Ross, 1976) (Note 8), who developed APT, dropped the assumptions on preferences and strict maximization. The big idea of APT is to look at which combinations of assets one would hold to rule out any arbitrage. Arbitrage is possible when two assets with the same risk have different returns. The APT, however, does not preclude arbitrage over dynamic portfolios. Therefore, the applications of the APT in the evaluation of managed portfolios contradict at least the spirit of the APT, which obtains price restrictions by assuming the absence of arbitrage. The model of (Ross, 1976) is based on the popular intuition that the security returns are affected by several, presumably a small number $k$ factors. This intuition can be view into a factor model written bellow:

$$
r_{i t}-u_{i}=b_{i 1} \delta_{1 t}+b_{i 2} \delta_{2 t}+\ldots+b_{i k} \delta_{k t}+e_{i t}
$$

Where $\delta$ 's are the standardized factor scores in that they have zero means and unit standard deviations and $b$ are the sensitivities of the security to the factors. The factors are designed so that they are orthogonal to each other 
and to the residual element $e$. In matrix notation, we can write for a sample of $n$ securities then we obtain equation (17)' as follow:

$$
R_{t}-M=B \Delta_{t}+E_{t}
$$

With $R_{t}$ and $M$ are the $n X 1$ vector of realize and expected returns, $B$ is the $n X k$ of sensitivities, $\Delta_{t}$ is the $n X 1$ vector of residuals. Further, (Ross, 1976) assumes that the market which consists of infinitely many securities is efficient in the sense that the payoff on an arbitrage portfolio, a zero cost portfolio with zero sensitivity is zero (Note 9). The factor model and no-arbitrage assumptions combined with a few other minor assumptions conduct to the pricing equation of the arbitrage price theory (APT) mentioned bellow:

$$
\mu_{i} \simeq \gamma_{0}+b_{i 1 \gamma 1} \delta_{i 2 \gamma 2}+\ldots+b_{i k \gamma k} \quad \text { written by matrix we have } \quad M \simeq l_{\gamma 0}+B \Gamma
$$

Where $l$ represents a $n X 1$ vector of one and $\mathbb{T}$ is a $k X 1$ vector of $\gamma$; The approximation $(\simeq)$ in the APT pricing equation arises in economies with finite number of securities because the total risk (variance) of the arbitrage portfolio is not completely diversifiable in a finite economy. The theoretical arguments provided by (Ross, 1976), (Dybvig, 1983) and (Grinblatt \& Titman, 1983) show that the average pricing error would empirically be negligibly small. (Shanken, 1982) argues that even if the average pricing error is small, individual pricing errors may be large.

Applying APT to real economy, the macroeconomics modulated independent state-space model was proposed by (Xu, 2000) with an aim to model the financial market in a state of general equilibrium. Unlike traditional APT, it further utilizes observed macroeconomic variables and indices to implement the concept of long-term equilibrium in economics. In general, the model takes the following form:

$$
\begin{array}{r}
y_{t}=B_{y t-1}+H_{z t-1}+\varepsilon_{t} \\
x_{t}=A_{y t}+e_{t} \\
z_{t}=C_{y t}+E_{v t}+\theta_{t}
\end{array}
$$

With $\varepsilon_{t}, e_{t}$ and $\theta_{t}$ are Gaussian white noises independent from each other, $\varepsilon_{t}$ is independent from both $z_{t-1}$ and $y_{t-1}, e_{t}$ and $\varepsilon_{t}$ are independent of $\mathrm{y}_{\mathrm{t}}$ and $v_{t}$ Specifically, $z_{t}$ consists of a number of macroeconomic indices and $v_{t}$ consists of a number of known non-market factors that affect the macroeconomy. Typically, $H_{z t-1}$ describes the indirect effect of the macroeconomic indices to the security market via the hidden factors $y_{t}$, and $C_{y t}$ describes the feedback effect of the market to the macroeconomic indices. $(\mathrm{Xu}, 2000)$ continues by considering the model which describes a capital market via both short-term and long-term dynamics. For short-term dynamics, $x_{t} ; y_{t}$ and perhaps $z_{t}$ move to reach an equilibrium in the sense that the series of $\varepsilon_{t}, e_{t}$ and $\theta_{t}$ become stationary white noises, while the parameters B; H; A; C; E and the statistics of $\varepsilon_{t}, e_{t}$ and $\theta_{t}$ can be regarded as relatively constant due to slow changing. For long-term dynamics, the parameters $\mathrm{B} ; \mathrm{H} ; \mathrm{A} ; \mathrm{C} ; \mathrm{E}$ and the statistics of $\varepsilon_{t}, e_{t}$ and $\theta_{t}$ are all changing to cohere to equilibrium.

\subsection{Dividend Discount Model (DDM)}

The fundamental value of an asset can be viewed as a function of three variables: the size, timing and uncertainty of the cash flows the asset will generate for investors over its lifetime. For equities, the cash flows are generally dividends and the uncertainty lies in the timing and growth of the firms' earnings and its subsequent ability to pay dividends. Since dividends historically have depended on the size and sustainability of earnings, both dividends and earnings are key determinants of the value of equity. To determine the expected price of an asset, we assume that investors use fundamental valuation techniques. The first model we consider is the dividend discount model (DDM) of stock prices. We consider a person who purchases a stock today for price $P t$ and sells it tomorrow for price $P_{t+1}$ and generates a rate of return on this investment of:

$$
r_{t+1}=\frac{D_{t}+\Delta P_{t+1}}{P_{t}}
$$

Where $r_{t+1}$ is the rate of return, $D_{t}$ the dividend payment received during the period the stock was held, $\Delta P_{t+1}$ measures the price of stock changing from the period $t$ to period $t+1$. This can also be written bellow: 


$$
1+r_{t+1}=\frac{D_{t}+P_{t+1}}{P_{t+1}}
$$

Then we obtain the equation (26) after arrangement.

$$
P_{t}=\frac{D_{t}}{1+r_{t+1}}+\frac{P_{t}}{1+r_{t+1}}
$$

We now consider a rational expectations approach to the determination of stock prices. In the context of stock prices, rational expectations signify investors understand equation (26) and that all expectations of future variables must be consistent with it. This means that:

$$
E_{t} P_{t}=E_{t}\left[\frac{D_{t}}{1+r_{t+1}}+\frac{P_{t+1}}{1+r_{t+1}}\right]
$$

Where $E_{t}$ signifies the expectation of a variable at the period $t$, then the stock price at time $t$ is observable therefore $E_{t} P_{t}=P_{t}$ means that:

$$
P_{t}=E_{t}\left[\frac{D_{t}}{1+r_{t+1}}+\frac{P_{t+1}}{1+r_{t+1}}\right]
$$

If we assume that the return on stock is expected to equal some constant value for all future periods $E_{t r_{t+k}}=r$ with $k=1,2,3 \ldots, n$ this helps us transform the equation (28) as follow:

$$
P_{t}=\frac{D_{t}}{1+r_{t+1}}+\frac{E_{t} P_{t+1}}{1+r_{t+1}}
$$

The equation (29) is specific example of what is known as first order stochastic difference equation (Note 10) because such equations are used in macroeconomics. In general, we can rewrite this equation as follows:

$$
y_{t}=a x_{t}+b E_{t} y_{t+1}
$$

The equation (30) holds in all periods, so under the assumption of rational expectations (Note 11), the agents understand the equation and formulate their expectation in a way that is consistent with it we have:

$$
E_{t} y_{t+1}=a E_{t} x_{t+1}+b E_{t} y_{t+2}
$$

By substitution in the equation (31), we obtain the equation written bellow as:

$$
y_{t}=a x_{t}+a b E_{t} x_{t+k} b^{2} E_{t} y_{t+N}
$$

Repeating this method by substituting in for $a b E_{t} x_{t+2}$, and then $a b E_{t} x_{t+3}$ and so on, we obtain the generalized and more compact form:

$$
P_{t}=\sum_{k=0}^{N-1} b^{k} E_{t} x_{t+k}+b^{N} E_{t} y_{t+N}
$$

If we compare very carefully the equation (29) and (30), we can understand that our stock price equation is specific case of first order stochastic difference equation with $y_{t}=P_{t} ; x_{t}=D_{t}$;

$a=\frac{1}{1+r}$ and $\quad b=\frac{1}{1+r}$ this implies that the stock price can express as follow: 


$$
P_{t}=\sum_{k=0}^{N-k}\left(\frac{1}{1+r}\right)^{k+1} E_{t} D_{t+k}+\left(\frac{1}{1+r}\right)^{N} E_{t} P_{t+N}
$$

We assume that the final term tends to zero as $\mathrm{N}$ get big we have $\lim _{n \rightarrow \infty}\left(\frac{1}{1+r}\right)^{n} E_{t} P_{t+N}=0$

The explanation is that if it did not hold then we could set all future values of $D_{t}$ equal to zero, and the stock price would still be positive. But a stock that never pays out should be inherently worthless, so this condition rules this possibility out. With this imposed, our solution becomes.

$$
P_{t}=\sum_{k=0}^{N-1}\left(\frac{1}{1+r}\right)^{k+1} E_{t} D_{t+k}
$$

Means that stock prices should equal a discounted present-value sum of expected future dividends, this equation is usually known as the dividend-discount model (DDM).The (Gordon, 1962) growth model is a useful special case that is often used as a benchmark for thinking about stock prices is the case in which dividends are expected to grow at a constant rate such as:

$$
E_{t} D_{t+k}=(1+g)^{k} D_{t}
$$

In this case, dividend-discount model predicts that the stock price should be given by:

$$
P_{t}=\frac{D_{t}}{1+r} \sum_{k=0}^{\infty}\left(\frac{1+g}{1+r}\right)^{k}
$$

This geometric series formula gets used a lot in modern macroeconomics, not just in examples involving the multiplier. Here we can use it as long as $\left(\frac{1+g}{1+r}\right)<1$ mean that as long as $r$ (the expected return on the stock market) is greater than $g$ (the growth rate of dividends).

\section{Model Specification, Estimation Method and Data Sources}

\subsection{Model Specification}

This study investigates the effect of macroeconomic variables on stock prices Cote d'Ivoire. Many researchers have developed multifactor models relating to a number of macroeconomic variables (Chen, Roll, \& Ross, 1986), (Jorion, 1991); (Ely \& Robinson, 1997); (Bilson \& al., 2001), (Chen \& Al, 2005) examined the relationship between macroeconomic variables and hotel stock returns and they incorporated natural log into the data in order to run the regression analysis. In the same way, (Rangvid, 2001) and (Gjerde \& Sættem, 1999) employed Vector Auto Regression (VAR) model and all variables have been converted into natural logarithm. However, macroeconomic variables such as money supply, industrial production index, interest rate and exchange rate have been used in a numerous research papers for Emerging Stock Market (ESM) studies. There are several theoretical justifications to explain the relationship between macroeconomic variables and stock prices (Homa \& Jaffe, 1971); (Mandelker \& Tandon, 1985); (Boudoukh \& Richardson, 1993). To explore long-run relationship between economic variables and stock prices we base our analysis on the model employed by (Bilson \& al., 2001). Therefore, the following econometric model is specified as follow:

$$
L n S P I=\beta_{0}+\beta_{1} L n I P I+\beta_{2} L n C P I+\beta_{3} L n I R+\beta_{4} L n E X R+\beta_{5} L n M_{2}+\Omega+\mu_{\mathrm{t}}
$$

Where $L n$ represents the natural logarithm, SPI is the stock prices, CPI denotes the consumers price index (inflation), the domestic interest rate is depicted by $I R, E X R$ is the real exchange rate, $M_{2}$ is the broad money supply, $\Omega$ is a Dummy variables to capture all qualitative data and $\mu_{\mathrm{t}}$ is the error term. We expected to have the following sign of our coefficients as follow: $\beta_{1}, \beta_{5}>0 ; \beta_{2}, \beta_{3}<0$ and $\beta_{4}>0$ or $\beta_{4}<0$

\subsection{Estimation Method and Data Sources}

Before conducted our empirical study, the time series properties of the variables need to be examines. Non-stationary time series data has often been regarded as a problem in empirical analysis. Working with non-stationary variables leads to spurious regression results from which further inference is meaningless when 
these variables are estimates in their levels. In order to overcome this problem there is a need for testing the stationarity of these micro-economic variables. The unit root and cointegration test on relevant economic variables are in order to determine time series characteristics. This test is important as it shows the number of times the variable has to be differenced to arrive at a stationary value. In general, economic variables which are stationary are called I (0) series and those which are to be differenced once in order to achieve a stationary value are called I (1) series. In testing for stationarity, the standard augmented Dickey-Fuller test (Dickey, 1979), (Fuller, 1979) and (Phillips-Perron, 1988) are performed to test the existence of unit root in order to establish the properties of individual series. The regression is estimated by equation (39) as follow:

$$
\Delta Y_{t-1}=\alpha+\beta Y_{t-1} \sum_{j=1}^{k} \gamma_{i} \Delta Y_{t-k}+\varepsilon_{t}
$$

Where $\Delta$ is the difference operator, $Y$ the series to being tested, $K$ is the number of lagged differencies, and $\varepsilon$ an error term. Beyond testing for the unit root, there is a need to establish whether the non-stationary variables are cointegrated so we follow the method developed by (Johansen, 1988) and (Juselius, 1990) to test for the presence of equilibrium relationship between economic variables. The concept of cointegration implies that, if there is a long run relationship between two or more non-stationary variables. Cointegration test is conducted after conducting a unit root test first on individual series and if the variables are integrated of order one; that is, I (1), the static model is estimated for cointegration regression. Secondly, the order of integration is evaluated, that is on the residual generated from static model. The t-statistics of the coefficient of the regression using $A D F$ test determines whether we should accept cointegration or not. With this cointegration test still error correction is better than and being adopted. Following this procedure, the Error Correction Model $(E C M)$ is very crucial in the cointegration literature as it drives from the fact that, if macro variables are integrated in order one and are cointegrated, they can be modeled as having been generated by Error Correction Model. The error correction model produces better short run forecasts that hold together in economic meaningful ways. Thus, we suggest the reparametrization of the initial vector auto regression $(V A R)$ in the familiar vector error- correction (VECM) formulated in equation (40). The general $\operatorname{VAR}(p)$ model can be written as:

$$
\Delta Y_{t}=\prod Y_{t-p}+\sum_{i=1}^{p-1} \prod i \Delta_{t-1}+\Phi B_{t}+v_{t}
$$

Where $Y_{t}$ is and $N X 1$ vector of the time series of interest, $v_{t} \sim I N(0, \Sigma)$ and $B_{t}$ contains the conditioning variable set. The order of VAR $p$ is assume finite and the parameters $\Pi i$, $\Pi$ and $\varnothing$ are assume constant. The long-run response matrix is $\prod$ and, if the case $\prod$ can be express as the product of two $N r$ matrixes $\varphi$ and $\omega^{\prime} s: \sum=\varphi \omega$ where $\omega$ contains the $\gamma$ cointegrating vectors and $\varphi$ is the loading matrix which contains the coefficients with which the cointegrating relationships enter the equations $\Delta Y_{t}$. As we mentioned earlier Johansen and Juselius methodology target is to test the existence of the long-run equilibrium relationship among the variables therefore the test is base on the maximum eigenvalue noted by ( $\lambda$ max $)$ including the trace statistic ( $\lambda$ trace) or the likelihood ratio ( $L$. $R$ ). The general overparameterized model is estimated with maximum $n$ lags denoted $p$. An error correction term is introduced in the model. Hence equation (41) is re-specified to include error-correction term (ECT) in this form:

$$
\begin{aligned}
& \Delta L n S P I=\beta_{0} \sum_{j=1}^{p} \delta \Delta L n S P I_{t-j}+\sum_{j=1}^{p} \gamma_{k} \Delta L n I P I_{t-j}+\sum_{j=1}^{p} \phi_{k}\left[\Delta L n C P I_{t-j}+\sum_{j-1}^{p} \chi_{k} \mid \Delta L n I R_{t-j}+\sum_{j=1}^{p} \delta_{k} \Delta L n E X R_{t-j}\right. \\
& +\sum_{j=1}^{p} \Delta_{L n M 2_{t-j}}+\psi\left[\operatorname{LnSPI} I_{t-1}-\hat{\theta}_{0}-\hat{\theta}_{1} L n I P I_{t-1}-\hat{\theta}_{2} L n C P I_{t-1}-\hat{\theta}_{3} \operatorname{LnIR} R_{t-1}-\hat{\theta}_{4} \operatorname{LnEXR_{t-1}}-\hat{\theta}_{5} \operatorname{LnM} 2_{t-1}\right]
\end{aligned}
$$

Where $\psi$ measures the adjustment speed between the short-run and long-run disequilibrium and is vector error correction term $(E C T)$ as independent variable in the estimation process will cover all the long-run information that was lost in the original estimation process, $\Delta$ is the first difference operator and $\varepsilon_{t}$ is a purely white noise term. The ECT should have a negative sign and significantly different from zero. The negative sign of $E C T$ means that the deviation event between actual and long-run equilibrium level would be adjusted back to the long-run relationship in the current periods to clear this discrepancy.

Furthermore, we perform the Granger-Causality test in order to examine the short-run relations among the five variables used in stock price regression equation. To solve this problem, we utilize the technique developed by (Granger, 1969) and improve later by (Sims, 1972). If we consider for example suppose 2 variables, say $X_{t}$ and $Y_{t}$, affect each other with distributed lags. The relationship between those variables can be captured by a VAR 
model .Then, if we want to test whether $X_{t}$ causes $Y_{t}$, we analyze that how much of the present $Y_{t}$ can be illustrated by lagged values of $Y_{t}$ and $X_{t}$. In the Granger causality we test null hypothesis that $X_{t}$ does not granger cause $Y_{i}$; and if we can reject the null hypothesis, it means that $X_{t}$ does Granger cause $Y_{t}$. So the bivariate regression form for the Granger causation is written as follows:

$$
\begin{gathered}
Y_{t}=\lambda_{0}+\sum_{i=1}^{l} \lambda_{i} Y_{t-i}+\sum_{i=1}^{l} \mu_{i} X_{t-i}+v_{t} \\
X_{t}=\lambda_{0}+\sum_{i=1}^{l} \lambda_{i} X_{t-i}+\sum_{i=1}^{l} \mu_{i} Y_{t-i}+\varepsilon_{t}
\end{gathered}
$$

Where the joint hypothesis of F-test based to Wald statistics for each equation are:

\subsection{Sources of Data}

$$
\mu_{0}=\mu_{1}=\mu_{2}=\mu_{3}=\ldots=\mu_{i}
$$

The quarterly data utilized for our study will be selected from the International Financial Statistics (IMF-FS-CDROM) published by the International Monetary Fund (IMF) covering the whole period 1999:1 to 2007:4. Where industrial production index (IPI) is production volume index numbers and inflation rate is defined by consumer price index (CPI); (IR) is the interest rate; the real exchange rate $(R E R)$ is computed as the ratio of foreign price proxied by consumer price to domestic consumer price multiplied by the nominal exchange rate of the domestic currency and $M_{2}$ is the real money balances reflecting demand for real money balance. Market movements and trends in the Cote d'Ivoire stock market are depicted by market indices namely the BRVM 10. This information is made available on the stock exchange market office website in order to allow even foreign investors to have information on a real time basis.

\section{Empirical Result and Interpretation}

\subsection{Empirical Results}

In this section, we first start by analyzing the summary of descriptive statistics of the variable, so table 1 presents a result. Sample mean, standard deviation, skewness and kurtosis, and the Jacque-Bera statistic and $p$-value have been reported. The high standard deviation of LnSPI with respect to the mean is an indication the high volatility in the stock market. From the p-values, the null hypothesis that SPI, IPI, CPI, IR, EXR and $M_{2}$ are normally distributed at $10 \%$ level of significance cannot be rejected. We second run the univariate augmented Dickey-Fuller $(A D F)$ and Phillip-Peron $(P P)$ unit root tests for each variable that enters the multivariate model following the methodology implemented by (Dickey \& Fuller, 1979) and (Phillips-Perron, 1988) testing for the significance of trend and no trend with non-stationary and assuming that the choice of lags is based to guarantee non-residual autocorrelation. The results over the period are reported in table 2 . The overall test shows that we fail to reject the stationary null hypothesis base on $A D F$ and $P P$ test at level. However the tests indicate that all variables contain a unit root at level while they are all first difference stationary. Thus, according the empirical foundation, we conclude that all variables follow the $I(1)$ process.

Turning to the cointegration test, we follow the popular procedure developed by (Johansen, 1988) and (Juselius, 1990). As we mentioned earlier the method is based on the statistic values such us maximum eigenvalue ( $\lambda$ max) the trace statistics ( $\lambda$ trace) or the likelihood ratio $(L R)$.These statistics are utilized to detect the number of cointegrating vectors between stock price index (SPI) and it determinants. To this purpose, we firstly proceed by finding the appropriate lag-length in order to make sure the gaussian structure of the residuals in the vector-error correction model (VECM). To overcome this problem, we use the criteria developed by using the Akaike Information criterion (AIC) and Schwarz Bayesian Criterion (SBC) in this form:

$$
\begin{gathered}
A I C(p)=\operatorname{Ln}\left(\frac{\operatorname{ssr}(p)}{p}\right)+(p+1) \frac{2}{T} \\
B I C(p)=\operatorname{Ln}\left(\frac{\operatorname{ssr}(p)}{T}\right)+(p+1) \frac{\operatorname{Ln} T}{T}
\end{gathered}
$$

Where $\operatorname{SSR}(p)$ is the sum of square residuals of the estimated $A R(p)$ the BIC estimator of $p, p$ is the value that minimizes $B I C(p)$ among the possible choices $p=0,1 \ldots, p_{\max }$ is the largest value of $p$ value considered. Because the regression decreases when add lag. In contrast, the second term increases when you add a lag. The BIC trades off these two forces so that the number of lag that minimizes the $B I C$ is a constant estimator of the true lag length (Waston, 1994). The difference between the $A I C$ and the $B I C$ is that the term " $L n T$ " in the $B I C$ is replace by " 2 " in the $A I C$, so the second in the $A I C$ is smaller then $T$ represent the simple. The result shows that the optimal lag length is $k=2$. 
Thirdly, we perform the cointegration test in order to determine the number of cointegrating vectors for different combinations of variables; table 3 displays the results.

Fourth, after getting the long-run cointegration relationship using (Johansen, 1988) and (Juselius, 1990) procedure, the error-correction model $(E C M)$ can be expressed and estimated with a more appropriate simple dynamic representation of the (ECM) equation (41). Thus, an error correction term lagging one period error-correction term $\left(E C T_{t-1}\right)$ is included as one of the independent variables in the general over parameterized error correction model of maximum sustainable yield equation. This term capture the long run relationship by attempt to correct deviations from the long run equilibrium path. Its coefficient can be interpreted as the speed of adjustment or the amount of disequilibrium transmitted each period to amount of stock price index (LnSP1). Results on table 4 represents the estimation of the over parameterized model.

After the Vector Error Correction Model (VECM) model is estimated, then we utilize two short-run dynamic analyses called Forecast Error Variance Decompositions (FEVD) and Impulse Response Functions (IRFs) for our study. Both analyses help us to examine the behavior of an error shock to each variable on its own future dynamics as well as on the future dynamics of the other variables in the VECM system (Gunasekarage, Pisedtasalasai, \& Power, 2004). In fact, FEVD is used to detect the causal relations among the variables. It also explains the degree at which a variable is explained by the shocks in all the variables in the system (Mishra, 2004). While Impulse Response Function is used to detect the dynamic interaction among variables. For computing the IRFs, it is necessary that the variables in the system are in ordered and that a moving average process represents the system. The results are reported respectively in table 5 and figure1.

Finally, the next step is to examine the existence of causality among variables. In VAR, a causality test, which is also called multivariate generalization of the Granger causality test, examines whether the lags of one variable $Y_{I}$ enter into the equation for another variable $Y_{2}$. More precisely, a variable $Y_{1}$ is said to Granger-cause another $Y_{2}$ if the present value of $Y_{2}$ can be predicted with greater accuracy by using past values of $Y_{l}$, all other information being identical (Thomas, 1997). In the case that $Y_{1}$ Granger-causes $Y_{2}$, but not vice versa, then the causality from $Y_{1}$ to $Y_{2}$ is unidirectional. On the other hand, if both variables Granger-cause each other, then it can be stated as bi-directional causality or feedback (Brooks, 2002). However, it is worth noting that Granger-causality basically means a correlation between the current value of one variable and the past (lags) value of others. It does not mean that movements of one variable physically cause movements of another (Brooks, 2002).The results are depicted in table 6 .

\subsection{Interpretation of Empirical Results}

In so doing, we performed univariate augmented Dickey-Fuller $(A D F)$ and Phillips-Peron $(P P)$ unit root tests for each variable that enters the multivariate model following the decision process proposed by (Dickey \& Fuller, 1979) and (Phillips-Perron, 1988) testing for the significance of trend and no trend with non-stationary and assuming that the choice of lags is based to guarantee non-residual autocorrelation. The results over the period 1999:1-2007:4 reported in table 2 fail to reject the null hypothesis at level based on the tests mentioned above. Therefore, LnSPI, LnIPI, LnCPI, LnIR, LnEXR and $\mathrm{LnM}_{2}$ contain a unit root in their levels form but not in their first differences form so they are integrated of order one, $I(1)$ process.

In addition, the second step was to perform the cointegration test using the famous method developed by (Johansen S., 1988) and (Juselius K., 1990). We found in our analysis that stock price index(LnSPI), industrial production index $(L n I P I)$, consumer price index $(L n C P I)$, domestic market rate $(L n I R)$, real exchange rate $(\operatorname{LnEXR})$ and real money balance $\left(M_{2}\right)$ are cointegrated at the 5\%(1\%) level of significance. Both the maximum eigenvalue $(\lambda \max )$ and the trace statistics ( $\lambda$ trace) tests identify a unique statistically significance vector with $(\lambda \max =0.751173 ; \lambda$ trace $=121.4322)$ see table 3 . However, we reject the null hypothesis that long-term relationship exist between stock price index (LnSPI) and it main determinants when the domestic interest rate $(L n I R)$ is employed as the basic determinant of the stock price index. Moreover, our over reparameterized model (VCEM) displays very meaningful result thus domestic interest rate (LnIR) and real exchange rate (LnRER) are all statistically significant at conventional significance levels $1 \%, 5 \%$ level table 4 . The estimated cointegrating vectors are giving economic meaning by the normalized equation on stock price index. Note that the normalization equation is only conducted if nonzero vector or vectors are confirmed by the cointegration test. The results of the normalized cointegrating vector tests are shown in table 8 bellow. The first normalized Equation (Note 12) is estimated as follow:

$$
\text { LnSPI=-5.663LnIPI + 42.497LnCPI - 28.539LnIR -6.558LnEXR-0.054 LnM }
$$

In fact, the normalized equation with $L n S P I$ indicates more meaningful result with domestic interest rate elasticity with positive coefficient (-28.53913) significantly different to zero, positive sign of real exchange rate ( $L n E X R)$ elasticity $(-6.558416)$, then we find also positive elasticity $(-0.053809)$ for real money balance $\left(L n M_{2}\right)$. Hence, according our empirical suggestions mentioned earlier, if we use stock price index as dependant variable, 
we fail to reject the null hypothesis of single cointegration at $5 \%$ significance level. This mean that the relevant variables utilized for stock price index function in Cote d'Ivoire are quite stable. Therefore, the long-run independent variables use in specifying the stock index function for this study seems to be good. Regarding Jansen, Thornton and (Dickey, 1991), the vector that makes economic sense is that the estimated coefficients are close to and have the same signs as those predicted by economic theory. According (Jansen, 1991) and (Dickey \& Thornton, 1991) cointegration analysis does not give estimates with structural interpretation regarding the magnitude of the parameters of the cointegrating vectors. Because cointegrating vectors merely imply long run, stable relationships among jointly endogenous variables, they generally cannot be interpreted as structural equations. Therefore, we continue our study by analyzing more deeply the effects of all relevant macro-variables on stock price index in Cote d'Ivoire.

Following the cointegration technique procedure, the short-run dynamics of the long-run stock price index function is analyzed by computing an error-correction model $(E C M)$ with lags length $(k=2)$ and report a significance F-test statistics which implying that there is an improvement in the overall significance of the model table 5. The result shows a correct sign (negative) meaningful and relatively good $E C T_{t-1}$ coefficient (-0.009419). These signify that the adjustment process to an exogenous shock is rather acceptable. In another words, it would take 0.94 of the quarters of stock price index (LnSPI) to come to equilibrium if an econometric shock of relevant factors occurred both. Furthermore, cointegration among stock price index (LnSPI) and its determinants can also be confirmed by the significance of the lagged error-correction term $\left(E C T_{t-1}\right)$ at the conventional level $1 \%$. This evidence from the test demonstrate that the selected determinants are important variables for long-run cointegration estimation vector but produce also a strong significant short-run impact on stock price index (LnSPI) function.

Moreover, the variance decomposition provided further evidence of relationships among the variables under investigation. The variance decomposition showed the proportion of the forecast error of one variable due to the other variables. Therefore, the variance decomposition makes possible to determine the relative importance of each variable in creating fluctuations in other variables (Ratanapakorn \& Sharma, 2007). Table 5 shows that the LnSPI index is relatively less exogenous in relation to other variables, such as LnIPI, LnCPI, LnIR, LnEXR and $\mathrm{LnM}_{2}$ because almost 40 percent of its variance was explained by its own shock after 16 quarters. LnIPI explains 1.13 percent impact on stock prices. Movements in other macroeconomic variables, i.e. explained forecast variance 42.34 percent, 6.85 percent, 1.33 percent, and 8.18 percent respectively for LnSPI. Turning to the impulse response function displayed in figure 1, we observe that LnIPI and $L n C P I$ seem to have immediate effect on LnSPI positive responses with long run association with positive standard deviation innovation in $L n C P I$. The result implies that the market efficiently allocate resources by adjusting to general increase in price levels in the long run. The responses of LnSPI to LnIR, LnEXR and $L n M_{2}$ are in line with findings by other researcher in both advanced and emerging markets. A shock in LnIR leads to a sharp reduction in LnSPI after 4 quarters; this explains the strong inverse relation between domestic interest rate and stock market investment in Cote d'Ivoire. The negative impact of the shock in exchange supports the cointegration results. From figure 1, we can also observe that a shock in $\mathrm{LnM}_{2}$ increase after 5 quarters thus, this support that money market plays important role.

In the last step of our analysis, we run the Granger-causality following the method of (Granger, 1969) and (Sims, 1972). The Granger causality test statistic is reported in table 6 reveals that there is unidirectional causality results as follow: i) Changes in consumer price index ( $L n C P I)$ Granger-cause changes in the stock price index (LnSPI); ii) Changes in the industrial production index (LnIPI) both Granger-cause consumer price index (LnCPI) and real money balance $\left(\mathrm{LnM}_{2}\right)$; iii) Changes in the Changes in consumer price index ( $\mathrm{LnCPI}$ ) Granger-cause the domestic interest rate $(L n I R)$; iv) Changes the in real money balance $\left(L n M_{2}\right)$ Granger-cause the real exchange rate $(\operatorname{LnEXR})$. The causality analysis also highlights that there is strong bi-directional relationship between stock price index (LnSPI) and domestic interest rate $(L n I R)$. The result indicates that none of Cote d'Ivoire's macroeconomic variables Granger-cause the stock index returns. This fact implies that macroeconomic variables might not be appropriate indicators to predict stock index returns. This also indicates that investors in the stock market did not intensively use the information of changes in macroeconomic factors when deciding their transactions during the study period. The inflation rate influences both the stock index returns and the money market movements. This may indicate that investors in both markets consider the inflation rate when calculating their expected returns. The unidirectional causality between the inflation rate and the stock index returns confirms the research by (Saunders \& Tress, 1981). The bi-directional causality between changes in the domestic interest rate and changes in the stock return in this country suggests that changes in the domestic interest rate might be used to predict the future stock price movement. Hence, the changes in the domestic interest rates could 
be a crucial instrument to predict and/or influence future changes in the stock index and the real sector of its economy.

\section{Conclusion}

In this study we investigate the role of macroeconomic variables in stock market movement during the period of January 1999 to December 2007. We employed Stock Price Index (SPI) namely BRVM10, industrial production index, consumer price index, domestic interest rate, real exchange rate and real money supply. We examined the long run relationship between share prices and group of macroeconomic variables using Johansen's multivariate cointegration tests. Short run dynamics were traced using impulse response function and forecast error variance decomposition analysis. We performed the Granger-Causality test in order to examine the short-run relations among our relevant variables used in the regression. To solve this problem, we utilize the technique developed by (Granger, 1969).

Cointegration analyses provide evidence in support of long run relationship between share prices and macroeconomic variables identified over the study period. Contrary to our hypothesis, inflation positively correlates with stock price index. This means that the stock market provide partly or full hedge against inflation. Our result support the finding of (Firth, 1979), (Anari \& Kolari, 2001), (Luintel \& Paudyal, 2006) and (Gultekin, 1983). The forecast error variance decomposition (FEVD) analysis test results indicate that inflation or consumer price index explains higher proportion of the variation of the stock prices index compared to domestic interest rate, industrial production index, real exchange rate and real money supply. Our suggestion base on the result is that potential investors should pay more attention to consumer price index $C P I$ followed by domestic interest rate $(I R)$, real money supply $\left(M_{2}\right)$ rather than real exchange rate EXR and industrial production index IPI. Turning to the impulse response function, we observe that industrial production index(IPI) and consumer price index $C P I$ seem to have immediate effect on SPI positive responses with long run association with positive standard deviation innovation in $C P I$. The result implies that the market efficiently allocate resources by adjusting to general increase in price levels in the long run. The responses of LnSPI to LnIR, LnEXR and LnM 2 are in line with findings by other researcher in both advanced and emerging markets. The Granger- causality test reveals that there is strong bi-directional relationship between stock price index (SPI)) and domestic interest rate (IR). Thus, changes in the domestic interest rate might be used to predict the future stock price movement.

The linkage between domestic stock price index movements and the selected macroeconomic variables for our study have been found to be very weak in Cote d'Ivoire. This may indicate that macroeconomic factors are not appropriate indicators to forecast the future behavior of the stock index movements in Cote d'Ivoire. This also means that the stock markets are not able to capture information about the changes in macroeconomic variables. The study suggests that appropriate monetary policies should be taken by monetary authorities to control inflation so that the volatility of the stock markets can be minimized. The increase in Industrial production can play significant positive role in development of the capital markets of Cote d'Ivoire. The countries authorities should therefore formulate such a policy which supports stock prices through the promotion of industrial production.

\section{References}

Abdullah, D. A., \& Hayworth, S. C. (1993). Macroeconometrics of stock price fluctuations. Quarterly Journal of Business and Economics, 32, 46-63.

Alexakis, P., \& Xanthakis, M. (1995). Day of the week effect on the Greek stock market. Applied Financial Economics, 5, 43-50. http://dx.doi.org/10.1080/758527670

Anari, A., \& Kolari, J. (2001). Stock prices and inflation. Journal of Financial Research, 24, 587-602.

Barnea, A., \& Downes, D. (June 1973). A re-examination of the empirical Distribution of Stock Price Change. Journal of the American Statistical Association.

Bilson, al., e. (2001). Stock Return and Inflation: A long Horizon. Pacific Basin Finance Journal.

Blattberg, R., \& Gondeds, N. (1974). A Comparison of the Stable and Student Distribution as statistical models for stock prices. Journal of Business, 47 April 244-80. http://dx.doi.org/10.1086/295634

Blattberg, R., \& Gonedes, N. (1974). A Comparison of the Stable and Student Distributions as Statistical Models for Stock Prices. Journal of Business, 47, 244-280. http://dx.doi.org/10.1086/295634

Blume, M. (1970). Portfolio Theory: A Step Towards Its Practical Application. Journal of Business, 43:2, pp. 152-174. http://dx.doi.org/10.1086/295262

Booth, al, e. (1994). On the Idea of the Moral Economy. The American Political Science Review, Vol 88, No 3: 653667. 
Boudoukh, J., \& Richardson, M. (1993). Stock Returns and Inflation: A Long-Horizon Perspective. American Economic Review, 83:5, 1346-55.

Brooks, C. (2002). Introductory Econometrics for Finance. Cambrige University.

Brown, S., \& Otsuki, T. (1990). Macroeconomic factors and the Japanese equity markets. New York: in The CAPMD project, Japanese Capital Markets, Harper and Row.

Chen, Al, e. (2005). The impact of macroeconomic and non-macroeconomic forces on hotel stock returns. International Journal of Hospitality Management, Vol 24 PP: 243-430. http://dx.doi.org/10.1016/j.ijhm.2004.06.008

Chen, N., Roll, R., \& Ross, S. (1986). Economic forces and the stock market. Journal of Business, 59, 383-403. http://dx.doi.org/10.1086/296344

Cheung, Y., \& Ng, L. (1988). International evidence on the stock exchange and aggregate economic activity. $J$. Empir. Fin, 5(3): 281-296. http://dx.doi.org/10.1016/S0927-5398(97)00025-X

Cheung, Y., Ho, P. Y.k., \& Draper, P. (1994). Intraday Stock Return Volatility:the Hong Kong Evidence. Pacific-Basin Finance Journal, 2, 261-276. http://dx.doi.org/10.1016/0927-538X(94)90020-5

Clark, P. (1973). A Subordinated Stochastic Process Model with Finite Variance for Speculative Prices. Econometrica, 41, 135-155. http://dx.doi.org/10.2307/1913889

Corhay, A., \& Rad, A. (1994). Daily returns from European stock markets. Journal of Business and Finance and Accounting, 21, 271-281. http://dx.doi.org/10.1111/j.1468-5957.1994.tb00318.x

Cowles, A., \& Jones, H. (1937). Some A Posteriori Probabilities in Stock Market Action. Econometrica, 5, 280-294. http://dx.doi.org/10.2307/1905515

Dhakal, D., Khandil, M., \& Sharma, C. (1993). Causality Between Money Supply and Share Prices: A VAR Investigation. Quaterly Journal of Business and Economics, Vol 32 N0.3 PP 52-74.

Dickey, D. A., \& Thornton, D. A. (1991). A Primer on cointegration with an Application to Money and Income. Great Britain: Macmillan press.

Dickey, D., \& Fuller, W. (1979). Distribution of the Estimators for Autoregressive Time Series with a Unit Root. Journal of the American Statistical Association, 74, p. 427-431. http://dx.doi.org/10.2307/2286348

Dickey, F. (1979). Distribution of the Estimators for Autoregressive time series with Unit Roots. Journal of American Statistical Associations.

Dickey. (1991). A Primer on Cointegration with an Application to Money and Income. Review, Federal Reserve Bank of St. Louis, 73, pp. 58-78.

Dybvig, P. (1983). An Explicit Bound on Deviations from APT Pricing in a Finite Economy. Journal of Financial Economics, 12, 483-496. http://dx.doi.org/10.1016/0304-405X(83)90045-4

Ely, P. D., \& Robinson, 1. K. (1997). Are stocks a hedge against inflation? International evidence using a long-run approach. Journal of International Money and Finance, 16, 141-67. http://dx.doi.org/10.1016/S0261-5606(96)00039-3

Engle, R., \& Granger, C. (1987). Co-Integration, error correction Representation, estimation and testing. Econometrica, 55:1251-1276. http://dx.doi.org/10.2307/1913236

Epps, M. L., \& Epps, T. W. (1976). The Stochastic Dependence of Security Prices Changes and Transaction Volumes: Implications for the Mixture-of-Distributions Hypothesis. Econometrica, 44(2), pp. 305-321. http://dx.doi.org/10.2307/1912726

Errunza, Hogan, Kini, \& Padmanabh. (1994). Conditional Heteroskedasticity and Global Stock Return Distributions. Financial Review, 29(3), 293-317. http://dx.doi.org/10.1111/j.1540-6288.1994.tb00399.x

Faff, R. (1988). An empirical test of the arbitrage pricing theory on Australian stock returns 1974-85. Accounting and Finance, 28, 2, 23-43. http://dx.doi.org/10.1111/j.1467-629X.1988.tb00143.x

Fama, E. (1965). The Behaviors of Stock Price. Journal of Business.

Fama, E. F. (1963). Mandelbrot and the Stable Paretian Hypothesis. Journal of Business, XXXVI (October, 1963), 420-29. http://dx.doi.org/10.1086/294633

Fama, E. F. (1965). Portfolio Analysis in a Stable Paretian Market. Management Science Science (January).

Fama, E. F. (1990). Stock prices, expected prices and real activity. J. Fin., 45(4): 1080-1089.

Fama, E., \& Gibbons, M. (1982). Inflation and Real Return and Capital Investment. Journal of Monetary 
Economics, Vol 9 PP. 297-324.

Firth, M. (1979). The Relationship between Stocks Market Returns and of Inflation. Journal of Finance, 34 (June 1979).

Fisher, I. (1930). The Theory of Interest. New York, NY:Macmillan.

French, \& Roll. (1986). Stock return variances: The arrival of information and the reaction of traders. Journal of Financial Economics, 17, 5-26.

Fuller, W. (1979). Dickey, D.A. and W.A. Fuller (1979), "Distribution of the Estimators for Autoregressive Time Series with a Unit Root. Journal of the American Statistical Association, 74, p. 427-431. http://dx.doi.org/10.2307/2286348

Fung, H. G., \& Lie, C. J. (1990). Stock market and economic activities: a causal analysis. Pacific-Basin Capital Markets Research, Amsterdam.

Ghysels, e. a. (2007). Handbook of financial time series. Business \& Economics, 1050 pages.

Gjerde, Ø., \& Sættem, F. (1999). Causal relations among stock returns and macroeconomic variables in a small, open economy. Journal of International Financial Markets, Institutions \& Money, 9, pp. 61-74. http://dx.doi.org/10.1016/S1042-4431(98)00036-5

Gordon, M. J. (1962). The Investment, Financing and Valuation of the Corporation. R. Irwin, Homewood Ill.

Granger, C. W. (1969). Investigating causal relations by econometric models and cross-spectral methods. Econometrica, 37, 424-438. http://dx.doi.org/10.2307/1912791

Grinblatt, M., \& Titman, S. (1983). Factor Pricing in a Finite Economy. Journal of Financial Economics, 12 , 497-507. http://dx.doi.org/10.1016/0304-405X(83)90046-6

Gultekin, N. (1983). Stock market returns and inflation: evidence from other countries. Journal of Finance, 38 , 49-65. http://dx.doi.org/10.2307/2327637

Gunasekarage, A., Pisedtasalasai, A., \& Power, D. (2004). Macroeconomic influence on the stock market.Evidence from market in south Asia. Journal of Emerging market and finance, Vol 3 No 3 P. 285-364. http://dx.doi.org/10.1177/097265270400300304

Habibullah, M., \& Baharamshah, A. (2000). Testing for informational efficient Market Hypothesis. The case of Maleysian stock Market. Issues of Monetary and Financial Economics. Study on Maleysian Economy.

Hagerman, R. (1978). Notes: more evidence on the distribution of security returns. Journal of Finance, 33, 1213-1221. http://dx.doi.org/10.2307/2326950

Hamao, Y. (1988). Empirical Examination of Arbitrage Pricing Theory: Using Japanese Data. University of California, USA. (Working Paper).

Har, W. M., Tan, A. L., \& Lim, C. H. (2008). Development economics: Theories and issues. Kuala Lumpur: Pustaka Prinsip [ISBN: 978-983-053-487-9] [109 pages].

Harris, L. (1986). Transaction Data Study of Weekly and Internal Patterns in Stock Returns. Journal of Financial Economics, 16: 99-117. http://dx.doi.org/10.1016/0304-405X(86)90044-9

Hendry, D. (1986). Econometric modeling with cointegrated variables: an overview. Oxford Bulletin of Economics and Statistics, 48, 201-212. http://dx.doi.org/10.1111/j.1468-0084.1986.mp48003001.x

Homa, K., \& Jaffe. (1971). Stock Market and Macroeconomic Performance in Greece. Greek Economic Review, 21(2) 65-84.

Hsieh, D. (1988). Statistical Properties of Daily Exchange Rates. Journal of International Economics, 24 (1988), 129-145. http://dx.doi.org/10.1016/0022-1996(88)90025-6

Huang, R., \& Kracaw, W. (1984). Market Return and Real Activity. A note Journal of Finance, Vol 39 PP 253-272.

Ibrahim, M. H. (1999). Macroeconomic variables and stock prices in Malaysia: an empirical analysis. Asian Economic Journal, 13, 219-231. http://dx.doi.org/10.1111/1467-8381.00082

Islam, M. (2003). The Kuala Lumpur stock market and economic factors: a general to specific Error Correction Model. Journal of the Academy of Business and Economics.

Jaffe, Jeffery \& Westerfield. (1985, 1989). The Week-End Effect in Common Stock Returns: The International Evidence. Journal of Finance, Vol. 40, June 1985, pp. 433-454.

Jansen, D. (1991). The Demand for Money in the United States: Evidence from Cointe-gration Tests. Journal of 
Money, Credit and Banking, 23, pp 155-68. http://dx.doi.org/10.2307/1992774

Jarque-Bera. (1987). A test for normality of observations and regression residuals. International Statistical Review, 55, 163-172. http://dx.doi.org/10.2307/1403192

Johansen, S. (1988). Statistical Analysis of Cointegrating Vectors. Journal of Economic Dynamics and Control, 231-54. http://dx.doi.org/10.1016/0165-1889(88)90041-3

Johansen, S. (1988). Statistical Analysis of Cointegrating Vectors. Journal of Economic Dynamics and Control.

Jorion, P. (1991). Bayesian and CAPM Estimators of the Means: Implications for Portfolio Selection. Journal of Banking and Finance, 15 (June 1991): 717-727. http://dx.doi.org/10.1016/0378-4266(91)90094-3

Juselius, K. (1990). Maximum likelihood estimation and inference on cointegration - with application to the demand for money. Economics and Statistics, 52, 169-210. Oxford Bulletin of.

Juselius, K. (1990). Maximum likelihood estimation and inference on cointegration - with application to the demand for money. Economics and Statistics, 52, 169-210. Oxford Bulletin of Statistics.

Kaneko, T., \& Lee, B. (1995). Relative importance of the economic factors in the U.S. and Japanese stock markets. J. Jpn. Int. Econ, 9(3): 209-307. http://dx.doi.org/10.1006/jjie.1995.1015

Keim, D., \& Stambaugh, R. (1984). A future investigation of the weekend effect in stock returns. Journal of Finance, 39,819-835. http://dx.doi.org/10.2307/2327945

Kwon, Chung, Shin, T., \& Bacon, F. (1997). The effect of macroeconomic variables on stock market returns in developingg markets. Multinational Business Review.

Lamoureux, C., \& Lastrapes, W. (1990). Persistence in variance, structural change, and the GARCH model. Journal of Business and Economic Statistics, 8, 225-234. http://dx.doi.org/10.2307/1391985

Lee, B. S. (1992). Causal relations among stock returns, interest rates, real activity and inflation. Journal of Finance, 47, 1591-1603. http://dx.doi.org/10.2307/2328955

Loesse, J. E. (2009). Cointegration an Causality between Financial Development and Economic Growth: Evidence from ECOWAS countries. European Journal of Economics, Finance and Administrative Siciences.

Luintel, K., \& Paudyal, K. (2006). Are Common Stocks A Hedge against Inflation?. Journal of Financial Research, XXIX, (1), 1-19. http://dx.doi.org/10.1111/j.1475-6803.2006.00163.x

Mandelbrot, B. (1962). A Class of Long-taileg Probability Distributions and the Empirical Distribution of City Sizes. Research note, Thomas J. Watson Research Center, Yorktown Heights, N.Y., May 23,.

Mandelker, G., \& Tandon, K. (1985). Common Stock Returns Real activity, Money and Inflation: Some International Evidence. Journal of International Money and Finance, 4 264-286. http://dx.doi.org/10.1016/0261-5606(85)90048-8

Martikainen, T., \& Puttonen, V. (1996). Sequential information arrival in stock and stock index derivatives markets. European Journal of Finance, 2:2, 207-217. http://dx.doi.org/10.1080/13518479600000005

Miller, M., \& Modigliani, F. (1961). Dividend Policy, Growth and The Valuation of Shares. The Journal of Business, Vol. 34, 1961, p: 411-433. http://dx.doi.org/10.1086/294442

Mishra, A. (2004). Stock Market and Foreign Exchange Market in India: Are They Related. South Asia Economic Journal, 5, 209. http://dx.doi.org/10.1177/139156140400500202

Mukharjee, T. K., \& Naka, A. (1995). Dynamic Relations between Macroeconomic Variables and the Japanese Stock Market: An application of a Vector Error Correction Model. The Journal of Financial Research, 18:2, 223-237.

Mukherjee, T. K., \& Naka, A. (1995). Dynamic relations between macroeconomic variables and the Japanese stock market: an application of a vector error correction model. Journal of Financial Research, 18, 223-237.

Nasseh, A., \& Strauss, J. (2000). Stock prices and domestic and international macroeconomic activity: a cointegration approach. Quarterly Review of Economics and Finance, 40, 229-245. http://dx.doi.org/10.1016/S1062-9769(99)00054-X

Officer, R. (1972). The Distribution of Stock Returns. Journal of the American Statistical Association, 340, (67), pp.807-12. http://dx.doi.org/10.2307/2284641

Omran, M. (2003). Time series analysis of the impact of real interest rates on stock market activity and liquidity in Egypt: Co-integration and error correction model approach. International Journal of Business, 8(3).

Peiró, A. (1999). Skewness in financial returns. Journal of Banking \& Finance, 23, 847-862. 
http://dx.doi.org/10.1016/S0378-4266(98)00119-8

Pesaran, H., Shin, Y., \& Smith, R. (2001). Bounds Testing Approaches to the Analysis of Level Relationship. Journal of Applied Econometric, 16, 289-326. http://dx.doi.org/10.1002/jae.616

Phillips-Perron. (1988). Testing for a Unit Root in Time Series Regression. Biometrika, 75, 335-346. http://dx.doi.org/10.1093/biomet/75.2.335

Praetz, P. (1972). The Distribution of Share Price Change. Journal of business, 45 january 49-55. http://dx.doi.org/10.1086/295425

Rangvid, J. (2001). Increasing convergence among european stock markets? a recursive common stochastic trends analysis. Economics Letters, 71(3), 383-389. http://dx.doi.org/10.1016/S0165-1765(01)00361-5

Rapach, D. (2002). Are real GDP levels nonstationary? Evidence from panel data tests. Southern Economic Journal, 68, 473-495. http://dx.doi.org/10.2307/1061713

Ratanapakorn, O., \& Sharma, S. (2007). Dynamic analysis between the US stock returns and the macroeconomic variables. Applied Financial Economics, Volume 17(5), pp. 369-377. http://dx.doi.org/10.1080/09603100600638944

Richardson, M., \& Smith, T. (1994). A Unified Approach to testing for Serial Correlation in Stock Returns. Journal of Business, 1994, 67 (3). http://dx.doi.org/10.2307/2327747

Rogalski, R. (1984). New findings regarding day of the week returns over trading and non trading periods: A note. Journal of Finance, December, pp. 1603-1614. http://dx.doi.org/10.1016/0022-0531(76)90046-6

Ross, S. (1976). The Arbitrage Theory of Option Pricing. Journal of Economic Theory, Vol 13 no. 3, pp. 341-360. http://dx.doi.org/10.1016/0022-0531(76)90046-6

Ross, S. (1976a, 1976b). The arbitrage theory of capital asset pricing. Journal of Economic Theory, 13, 341-60.

Saunders, A., \& Tress, R. (1981). Inflation and Stock Market Returns: Some Australian Evidence. Economic Record, 57(156): 58-66. http://dx.doi.org/10.1111/j.1475-4932.1981.tb01700.x

Shanken, J. (1982). The Arbitrage Pricing Theory? It is Testable. Journal of Finance, 37, 1129-1140. http://dx.doi.org/10.2307/2327839

Sims, C. (1972). Money Icome and Causality. American Economic Review, 62 PP540-52.

Smirlock, M., \& Starks, L. (1986). Day of the week and intraday effects in stock returns. Journal of Financial Economics, Vol.17, (1986), pp197-210. http://dx.doi.org/10.1016/0304-405X(86)90011-5

Tachiwou, A. M. (2010). Stock Market Development and Economic Growth: The Case of West African Monetary Union. International Journal of Economics and Finance, Vol. 2, No. 3; August 2010.

Tauchen, G., \& Pitts, M. (1983). The price variability-volume relationship on speculative markets. Econometrica, vol. 51, pp. 485-505. http://dx.doi.org/10.2307/1912002

Teichmoeller, J. (1971). A Note on the Distribution of Stock Price Changes. Journal of the American Statistical Association, 66 (1971), 282-284. http://dx.doi.org/10.2307/2283922

Thomas, R. (1997). Modern Econometrics: an Introduction. Addison-Wesley: Harlow.

Valkanov, a. a. (2006). Forecasting Realized Volatility: A Bayesian Model Averaging Approach. Forthcoming in Handbook of Economic Forecasting.

Vuyyuri, S. (2005). Relationship between real and financial variables in India: A cointegration analysis. [Online] Available: $\mathrm{http}: / / \mathrm{ssrn} . \mathrm{com} / \mathrm{abstract}=711541$

Waston, M. W. (1994). Vector Autoregression and Cointegration Chap.14 Hand book of econometrics Volume $I V$. Amsterdam: Edit by Robert Engel and Daniel McFadden.

Westerfield, R. (1977). The distribution of common stock price changes: An application of transactions time and subordinated stochastic models. Journal of Financial and Quantitative Analysis, Vol. 12, pp. 743-765. http://dx.doi.org/10.2307/2330254

$\mathrm{Xu}$, L. (2000). Temporal byy learning for state space approach,hidden markov model and blind source separation. IEEE Trans. on Signal Processing, 48:2132-2144. http://dx.doi.org/10.1109/78.847796

Yadav, P. K., Paudyal, K., \& Pope, P. (1999). Non-linear Dependence in Stock Returns: Does Trading Frequency Matter? Blackwell Publishers Ltd.

Yayah, K. (2009). Inflation and Financial Development: Cointegration and Causality Analysis for UEMOA Analysis. International Research Journal of Finance and Economics, ISSN 1450-2887 Issue 27. 


\section{Notes}

Note 1. Formerly known as the West African Monetary Union (WAMU/UMOA), the West African Economic and Monetary Union (UEMOA) were founded on 10 January 1994 in response to the devaluation of the common currency, the CFA Franc, on 11 January 1994.

Note 2. The Economic Community of West African States (ECOWAS) is a regional group of fifteen countries, founded in 1975. Its mission is to promote economic integration in "all fields of economic activity.

Note 3. Fama discussed that:'By definition, a stable paretian distribution is any distribution that is stable or invariant under addition. That is, the distribution of sums of independent, identically distributed, stable paretian variables is itself stable paretian and, except for origin and scale, has the same form as the distribution of the individual summands. Most simply, stability means that the values of the parameters $\alpha$ and $\beta$ remain constant under addition" (Fama, 1965. p.43).

Note 4. The expected value of kurtosis for normal distribution random variable is 3. Consequently, a value of zero for the excess kurtosis corresponds to normality (Nanjand and Yang 1991).

Note 5. In fact $y_{t}$ is a two-state Markov chain with probabilities $\left.\operatorname{Pr}\left(y_{t}=1\right) / y_{t-1}=1\right)=\left(p^{3}+(1-p)^{3}\right) / p_{s}$ and $\operatorname{Pr}\left(y_{t}=0 / y_{t-1}=0\right)=1 / 2$

Note 6. $\beta$ (The beta) is the sensitivity of the expected excess asset returns to the expected excess market returns.

Note 7. In finance, Jensen's alpha (or Jensen's Performance Index, ex-post alpha) is used to determine the abnormal return of a security or portfolio of securities over the theoretical expected return.

Note 8. Ross kept the idea that firms and stocks are looking for profit maximizing opportunities, and the market was hard to beat. Rather than evolving an equilibrium condition for the market from consumer preferences as Sharpe did, Ross snapped the market equilibrium onto the investors, merely assuming that the search for arbitrage would keep investors at or near the CAPM-derived equilibrium.

Note 9. Strictly speaking, the APT shows that if the payoffs on a sequence of arbitrage portfolios are bounded while the variance is not, then the sum of squared deviations from the pricing equation will be bounded. See Huberman (1982).

Note 10. Stochastic means random or incorporating uncertainty. It applies to this equation because agents do not actually know $P t+1$ but instead formulate expectations of it.

Note 11. See (Karl Whelan, 2005)

Note 12. Similar methodology was also used to estimate the equation and to explore the long-run relationships in the most recent studies (Nishat and Shaheen, 2004; Ratanapakorn and Sharma, 2007; Humpe and Macmillan, 2009). This equation was estimated by using E-views software.

Table 1. Summary Statistics of the Variable: 1999:1 to 2007:4

\begin{tabular}{|l|c|c|c|c|c|c|}
\cline { 2 - 7 } \multicolumn{1}{c|}{} & LNSPI & LNIPI & LNCPI & LNIR & LNEXR & LNM2 \\
\hline Mean & 107.6947 & 98.09639 & 110.2553 & 4.836389 & 110.9561 & 1190.933 \\
\hline Median & 89.68 & 100.95 & 110.71 & 4.95 & 114.415 & 1241.365 \\
\hline Maximum & 221.24 & 120.57 & 122.53 & 4.95 & 119.22 & 1847.27 \\
\hline Minimum & 73.04 & 73.76 & 96.81 & 3.75 & 98.98 & 91.56 \\
\hline Std. Dev. & 42.49842 & 11.70381 & 8.291453 & 0.327782 & 6.60608 & 437.9314 \\
\hline Skewness & 1.33366 & -0.15928 & -0.108375 & -2.53306 & -0.43986 & -1.396684 \\
\hline Kurtosis & 3.487135 & 2.174923 & 1.76011 & 7.553295 & 1.627506 & 4.587269 \\
\hline Jarque-Bera & 11.02784 & 1.173349 & 2.37646 & 69.59701 & 3.986473 & 15.4835 \\
\hline Probability & 0.00403 & 0.556174 & 0.30476 & 0 & 0.136254 & 0.000434 \\
\hline Observations & 36 & 36 & 36 & 36 & 36 & 36 \\
\hline
\end{tabular}

Source: Computation from data used in Regression Analysis. 
Table 2. Univariate Unit Root Tests

\begin{tabular}{|l|cccc|}
\hline \multirow{3}{*}{ Test/variables } & ADF statistics & \multicolumn{3}{l|}{ Phillips-Perron Statistics } \\
\cline { 2 - 5 } Level & No trend & Trend & No Trend & Trend \\
LnSPI & & & & \\
LnIPI & 0.876038 & -2.00516 & 1.636299 & -0.912586 \\
LnCPI & -0.656576 & -3.36626 & -0.651063 & -3.141336 \\
LnIR & 2.927329 & -3.87575 & 5.112956 & -3.293818 \\
LnEXR & -1.061068 & -0.68342 & -1.013204 & -1.21705 \\
LnM2 & 1.025847 & -1.78002 & 0.629647 & -2.482283 \\
First Difference & 0.586508 & -2.72164 & 0.637369 & -2.329318 \\
$\Delta$ LnSPI & & & & \\
$\Delta$ LnIPI & $-4.145278^{*}$ & $-4.95864^{*}$ & $-3.332823^{*}$ & -3.824597 \\
$\Delta$ LnCPI & $-8.04117^{*}$ & $-7.7407^{*}$ & $-7.880663^{*}$ & $-7.949323^{*}$ \\
$\Delta$ LnIR & $-4.306294^{*}$ & $-7.16679^{*}$ & $-4.684158^{*}$ & $-6.786738^{*}$ \\
$\Delta$ LnEXR & $-3.096866^{*}$ & -3.45876 & $-5.948204^{*}$ & $-6.384597^{*}$ \\
$\Delta$ LnM2 & $-3.382588^{*}$ & -3.39314 & $-5.240493^{*}$ & $-5.205201^{*}$ \\
\hline
\end{tabular}

Source: Computation from data used in Regression Analysis.

The table shows univariate unit root tests. The notation SPI, IPI, CPI, IR, EXR and $M_{2}$ indicate respectively the stock price index, industrial production index, consumer price index, nominal interest rate, real exchange rate and the real money supply. The $\Delta$ denotes first-difference derivation. The asterisks $*, * *$, and $* * *$ denote statistical significance at 1\%,5\%, and 10\% levels, respectively. McKinnon (1980) critical values are used for rejection of the null unit root.

Table 3. Johansen Cointegration Test

\begin{tabular}{|ll|cccc|}
\hline \multirow{2}{*}{$\begin{array}{l}\text { Null } \\
\text { hypothesis }\end{array}$} & $\begin{array}{l}\text { Alternative } \\
\text { hypothesis }\end{array}$ & Maximal & \multicolumn{4}{|c|}{$\begin{array}{c}\text { Likelihood Ratio } \\
\text { LR/Trace test }\end{array}$} \\
\cline { 3 - 6 } & & $\begin{array}{c}\text { Eigenvalue test } \\
(\lambda \text { max })\end{array}$ & $\begin{array}{c}\text { Statistics } \\
(\lambda \text { trace })\end{array}$ & $\begin{array}{c}5 \% \text { critical } \\
\text { Value (CV) }\end{array}$ & $\begin{array}{c}1 \% \text { critical } \\
\text { Value(CV) }\end{array}$ \\
\hline $\mathrm{r}=0$ & $\mathrm{r}=1$ & 0.751173 & 121.4322 & 104.94 & 114.36 \\
$\mathrm{r} \leq 1$ & $\mathrm{r}=2$ & 0.56729 & 74.13821 & 77.74 & 85.78 \\
$\mathrm{r} \leq 2$ & $\mathrm{r}=3$ & 0.441618 & 45.65683 & 54.64 & 61.24 \\
$\mathrm{r} \leq 3$ & $\mathrm{r}=4$ & 0.395862 & 25.8446 & 34.55 & 40.49 \\
$\mathrm{r} \leq 4$ & $\mathrm{r}=5$ & 0.213264 & 8.710216 & 18.17 & 23.46 \\
$\mathrm{r} \leq 5$ & $\mathrm{r}=6$ & 0.016187 & 0.554877 & 3.74 & 6.4 \\
\hline
\end{tabular}

Source: Computation from data used in Regression Analysis.

This table displays Johansen tests for cointegration. The $\lambda$-max and $\lambda$-trace (L.R) are Johansen's maximum eigenvalue and trace eigenvalue statistics for testing cointegration. Critical values (C.V.) denotes rejection of the hypothesis at $5 \%(1 \%)$ significance level, L.R. test indicates 1 cointegrating equation at $5 \%(1 \%)$ significance level. 
Table 4. Estimated Error-Correction Model regression with Lags Length $k=2$

\begin{tabular}{|c|c|c|c|}
\hline Independent variable & & Coefficients & Standard Error \\
\hline$E($ constant $)$ & & -8.626390 & 13.38628 \\
\hline$\Delta Z n I F l_{t-1}$ & & 0.042309 & 0.271892 \\
\hline $\sin 2 P_{t-2}$ & & -0.083364 & 0.314189 \\
\hline$\triangle L n C P T_{:-1}$ & & 0.164381 & 2.977515 \\
\hline$\triangle E n C P T_{:-2}$ & & -1.289521 & 2.867015 \\
\hline$\triangle L n l R_{t-1}$ & & $-20.62944 * *$ & 16.49203 \\
\hline$\Delta \operatorname{Ln} l R_{\mathrm{r}-\mathrm{z}}$ & & $-39.43517 * * *$ & 15.49903 \\
\hline$A \operatorname{LnEXR_{t-1}}$ & & $-1.743373 *$ & 1.667597 \\
\hline$A L n E X K_{t-2}$ & & -1.566281 & 1.778403 \\
\hline $\sin 2 \pi 2:-1$ & & -0.012648 & 0.014109 \\
\hline $\sin 22_{6} \rightarrow$ & & -0.010727 & 0.014381 \\
\hline$E C T_{:-1}$ & & $-0.009419 *$ & 0.008783 \\
\hline$R^{2}$ & 0.397 & & \\
\hline$R^{2}$ & 0.081 & & \\
\hline $2 W$ & 1.574796 & & \\
\hline Fistatistif & 1.257155 & & \\
\hline $\operatorname{Prab}(F, s t a t i s t t c)$ & 0.312861 & & \\
\hline 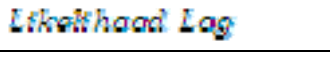 & -154.6665 & & \\
\hline Observation & 36 & & \\
\hline
\end{tabular}

Source: Computation from data used in Regression Analysis.

Note: F-test result indicates the overall significance of the model. The asterisks $* * *, * *$ and * implies statistically significant at $1 \%, 5 \%$ and at $10 \%$ level respectively. 
Table 5. Forecast Error Variance Decomposition

\begin{tabular}{|c|c|c|c|c|c|c|c|c|}
\hline VCD of & Month & S.E. & LNSPI & LNIPI & LNCPI & LNIR & LNEXR & LNM2 \\
\hline \multirow{5}{*}{ LnSPI } & 1 & 9.303239 & 100 & 0 & 0 & 0 & 0 & 0 \\
\hline & 4 & 20.34203 & 60.30442 & 1.12363 & 17.65572 & 8.623911 & 2.32687 & 9.96545 \\
\hline & 8 & 25.53197 & 45.86824 & 1.40536 & 32.72726 & 7.898947 & 1.695746 & 10.40445 \\
\hline & 12 & 28.63063 & 42.38315 & 1.135652 & 39.21279 & 6.609144 & 1.40124 & 9.258021 \\
\hline & 16 & 30.6463 & 40.19216 & 1.129129 & 42.34333 & 6.82589 & 1.333392 & 8.176105 \\
\hline \multirow{5}{*}{ LnIPI } & 1 & 5.969494 & 5.941891 & 94.05811 & 0 & 0 & 0 & 0 \\
\hline & 4 & 9.251532 & 9.326831 & 42.89503 & 8.810315 & 0.244296 & 14.59704 & 24.12649 \\
\hline & 8 & 10.41789 & 13.7763 & 35.54658 & 10.6256 & 1.469239 & 14.73827 & 23.84402 \\
\hline & 12 & 10.74763 & 13.19626 & 33.86244 & 10.51717 & 5.153805 & 14.63158 & 22.63874 \\
\hline & 16 & 11.56301 & 12.72919 & 29.40132 & 12.29557 & 11.76616 & 13.46031 & 20.34745 \\
\hline \multirow{5}{*}{ LnCPI } & 1 & 0.887086 & 15.83696 & 2.205205 & 81.95783 & 0 & 0 & 0 \\
\hline & 4 & 1.556651 & 16.24245 & 3.985453 & 66.66489 & 1.711102 & 6.01762 & 5.378483 \\
\hline & 8 & 2.197626 & 15.57116 & 2.475851 & 61.74319 & 13.80679 & 3.292894 & 3.110116 \\
\hline & 12 & 2.817813 & 11.07239 & 2.431625 & 42.13938 & 39.38342 & 2.341761 & 2.631422 \\
\hline & 16 & 3.932043 & 6.762505 & 2.267055 & 24.03959 & 61.25482 & 1.970368 & 3.705655 \\
\hline \multirow{5}{*}{ LnIR } & 1 & 0.099682 & 9.935614 & 0.115234 & 15.78488 & 74.16427 & 0 & 0 \\
\hline & 4 & 0.179805 & 23.72829 & 2.716145 & 11.80913 & 61.22894 & 0.164907 & 0.35259 \\
\hline & 8 & 0.273243 & 17.23644 & 2.633299 & 15.2685 & 62.73108 & 0.786746 & 1.343935 \\
\hline & 12 & 0.420822 & 14.49321 & 1.559116 & 27.27712 & 51.96486 & 1.207233 & 3.498469 \\
\hline & 16 & 0.602794 & 16.23547 & 0.9435 & 35.83282 & 41.36643 & 1.054548 & 4.567234 \\
\hline \multirow{5}{*}{ LnEXR } & 1 & 1.471553 & 2.390338 & 9.251071 & 12.21705 & 0.364716 & 75.77683 & 0 \\
\hline & 4 & 2.441585 & 3.01713 & 5.292907 & 4.870959 & 2.08439 & 80.72583 & 4.008784 \\
\hline & 8 & 2.884862 & 2.995305 & 4.026611 & 4.045679 & 9.869893 & 68.94101 & 10.1215 \\
\hline & 12 & 3.282966 & 2.337964 & 3.272337 & 3.352137 & 27.25131 & 53.51428 & 10.27198 \\
\hline & 16 & 4.066184 & 2.776082 & 2.678515 & 5.032821 & 45.82389 & 35.06561 & 8.62308 \\
\hline \multirow{5}{*}{ LnM2 } & 1 & 144.8254 & 1.113164 & 4.473146 & 3.716108 & 0.332097 & 5.039874 & 85.32561 \\
\hline & 4 & 202.4666 & 4.980867 & 13.07947 & 4.204225 & 2.471812 & 6.133682 & 69.12995 \\
\hline & 8 & 229.9745 & 7.508906 & 10.98257 & 9.257073 & 4.898737 & 12.74327 & 54.60945 \\
\hline & 12 & 261.1205 & 9.740444 & 8.632423 & 16.55554 & 8.819003 & 12.2803 & 43.97229 \\
\hline & 16 & 290.3899 & 12.2629 & 6.984989 & 22.63253 & 11.06768 & 10.20916 & 36.84274 \\
\hline & \multicolumn{8}{|c|}{ Cholesky Ordering: LNSPI LNIPI LNCPI LNIR LNEXR LNM2 } \\
\hline
\end{tabular}

Source: Computation from data used in Regression Analysis 
Table 6. Pairwise Granger Causality Tests Lags: 2 Sample: 1999:1 2007:4

\begin{tabular}{|c|c|c|}
\hline Null Hypothesis: & F-Statistic & Probability \\
\hline LNIPI does not Granger Cause LNSPI & 0.71393 & 0.49812 \\
\hline LNSPI does not Granger Cause LNIPI & 0.97124 & 0.39059 \\
\hline LNCPI does not Granger Cause LNSPI & 3.44469 & 0.04547 \\
\hline LNSPI does not Granger Cause LNCPI & 0.20556 & 0.81537 \\
\hline LNIR does not Granger Cause LNSPI & 3.52961 & 0.04247 \\
\hline LNSPI does not Granger Cause LNIR & 16.1715 & $1.90 \mathrm{E}-05$ \\
\hline LNEXR does not Granger Cause LNSPI & 1.54173 & 0.23104 \\
\hline LNSPI does not Granger Cause LNEXR & 0.01619 & 0.98395 \\
\hline LNM2 does not Granger Cause LNSPI & 0.55908 & 0.57778 \\
\hline LNSPI does not Granger Cause LNM2 & 0.76796 & 0.47317 \\
\hline LNCPI does not Granger Cause LNIPI & 2.07494 & 0.14381 \\
\hline LNIPI does not Granger Cause LNCPI & 6.74408 & 0.00393 \\
\hline LNIR does not Granger Cause LNIPI & 0.09299 & 0.91147 \\
\hline LNIPI does not Granger Cause LNIR & 0.25976 & 0.77301 \\
\hline LNEXR does not Granger Cause LNIPI & 0.16897 & 0.84536 \\
\hline LNIPI does not Granger Cause LNEXR & 0.04693 & 0.95423 \\
\hline LNM2 does not Granger Cause LNIPI & 1.40208 & 0.26227 \\
\hline LNIPI does not Granger Cause LNM2 & 2.5443 & 0.09593 \\
\hline LNIR does not Granger Cause LNCPI & 0.53282 & 0.59258 \\
\hline LNCPI does not Granger Cause LNIR & 2.88 & 0.0723 \\
\hline LNEXR does not Granger Cause LNCPI & 0.26753 & 0.76713 \\
\hline LNCPI does not Granger Cause LNEXR & 1.79845 & 0.18353 \\
\hline LNM2 does not Granger Cause LNCPI & 1.53383 & 0.2327 \\
\hline LNCPI does not Granger Cause LNM2 & 1.15768 & 0.32831 \\
\hline LNEXR does not Granger Cause LNIR & 0.63308 & 0.53813 \\
\hline LNIR does not Granger Cause LNEXR & 0.05342 & 0.94807 \\
\hline LNM2 does not Granger Cause LNIR & 0.21528 & 0.80759 \\
\hline LNIR does not Granger Cause LNM2 & 1.11841 & 0.34049 \\
\hline LNM2 does not Granger Cause LNEXR & 2.85479 & 0.07383 \\
\hline LNEXR does not Granger Cause LNM2 & 0.43 & 0.65459 \\
\hline
\end{tabular}

Source: Computation from data used in Regression Analysis.

Table 7. Normalized Cointegrating Coefficients

\begin{tabular}{|c|c|c|c|c|c|c|}
\hline LnSPI & LnIPI & LnCPI & LnIR & LnEXR & LnM2 & Constant \\
\hline 1 & -5.663553 & 42.49626 & -28.53913 & -6.558416 & -0.053809 & -2706.647 \\
\hline Standard Error & 1.23763 & 13.0188 & 22.1836 & 2.59102 & 0.02915 & \\
\hline t-value & 3.189908 & 5.052602 & -3.069812 & -1.594844 & -3.004792 & \\
\hline
\end{tabular}

Source: Computation from data used in Regression Analysis 


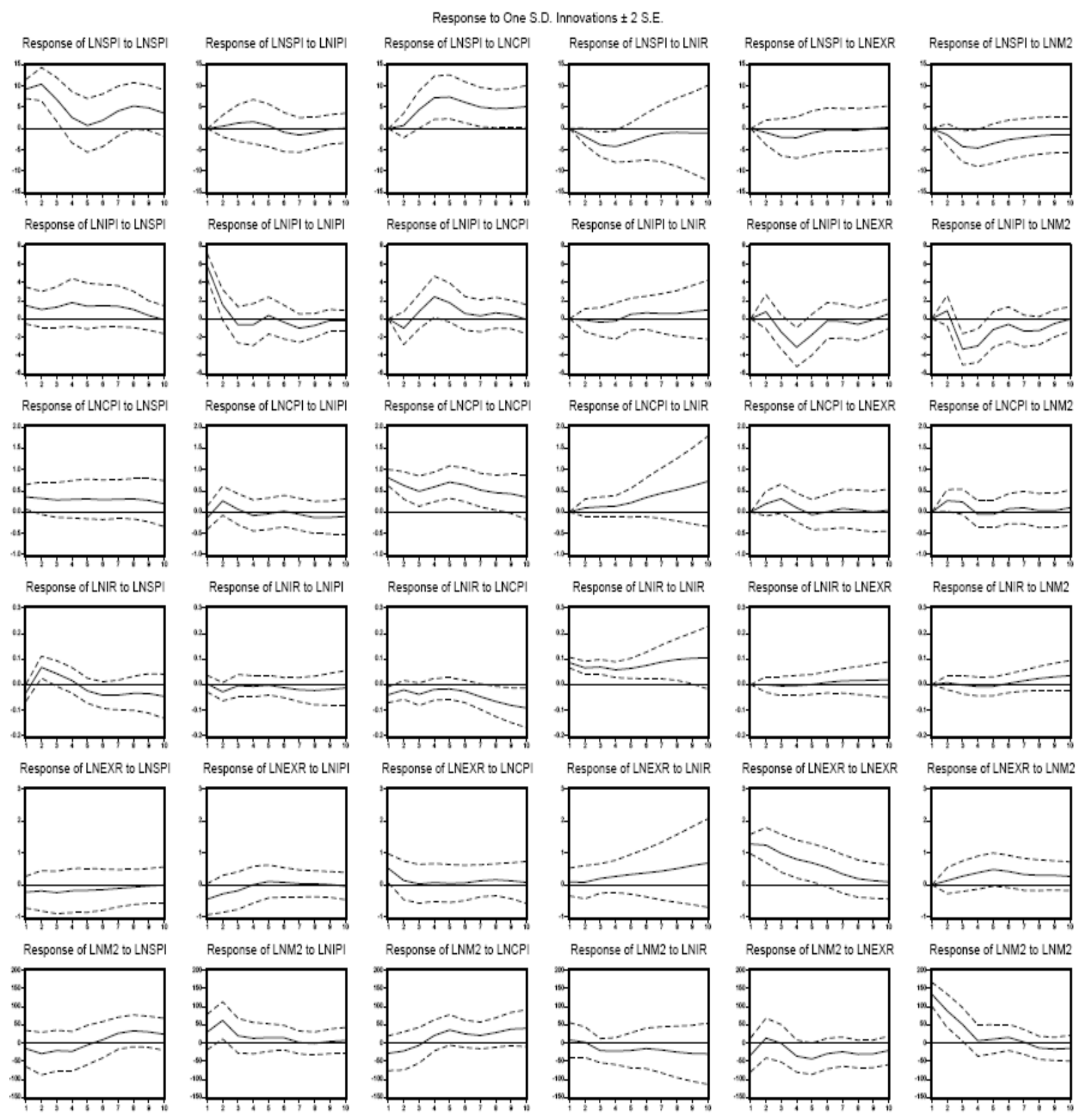

Figure 1. Impulse Response Function 